\title{
Scenario of Plant Breeding in Nepal and Its Application in Rice
}

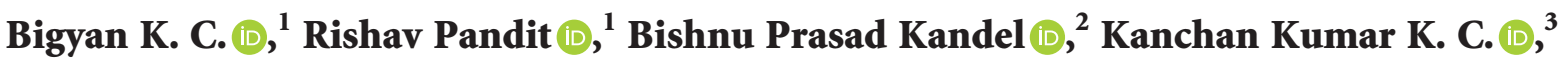 \\ Arpana K. C. (D), ${ }^{4}$ and Mukti Ram Poudel $\mathbb{D D}^{5}$
}

\author{
${ }^{1}$ Department of Plant Breeding, PG Program, Institute of Agriculture and Animal Science (IAAS), Tribhuvan University, \\ Kirtipur, Nepal \\ ${ }^{2}$ Purwanchal Agriculture Campus (PAC), Gauradaha, Jhapa, Nepal \\ ${ }^{3}$ Department of ICT and Extended Learning, NIST Foundation, Lainchaur, Kathmandu, Nepal \\ ${ }^{4}$ Department of Environmental Science, PG Program, Goldengate International College, Tribhuvan University, Battisputali, \\ Kathmandu, Nepal \\ ${ }^{5}$ Institute of Agriculture and Animal Science (IAAS), Paklihawa Campus, Siddharthanagar-1, Rupandehi, Nepal
}

Correspondence should be addressed to Bigyan K. C.; bkc.plb2018@iaas.edu.np

Received 13 February 2021; Accepted 19 June 2021; Published 30 June 2021

Academic Editor: Neeti Sanan Mishra

Copyright (C) 2021 Bigyan K. C. et al. This is an open access article distributed under the Creative Commons Attribution License, which permits unrestricted use, distribution, and reproduction in any medium, provided the original work is properly cited.

Rice, the number one staple food crop of Nepal, contributes nearly $20 \%$ to the agricultural gross domestic product, almost $7 \%$ to gross domestic product, and supplies with $40 \%$ of the food calorie consumption of Nepalese people. Despite of increasing production, the national demand of rice cannot be fulfilled, and billions of rupees are spent yearly for importing rice from India. This article reviews history, recent scenario, prospects, and importance of rice breeding research in Nepal for self-sufficiency. Though plant breeding inception point in Nepal was 1951, the systematic research in rice was started from 1972 after the establishment of the National Rice Research Program. Introduction and evaluation of high yielding exotic germplasm of rice was the initial rice breeding activities. After analysing several foreign materials, $\mathrm{CH}-45$ variety of rice was first recommended in 1959 . Nepal Agriculture Research Council (NARC), the leading organisation for rice varietal improvement to date, has been doing rice research activities such as germplasm conservation, exchange, varietal development, verification of technologies, and knowledge updates in collaboration with various organizations. International Rice Research Institute (IRRI), since 1966, has been playing an important role in Nepal's rice research. Major plant breeding achievements are introduction of exotic materials and their evaluation, local landraces identification, collection and analysis, crossing of local landraces with exotic genetic materials, heterosis breeding, tissue culture technology, genetic marker technology, and National Genebank. RAPD and SSR, DNA-based markers, are mostly used for diversity appraisal and selecting desirable genotypes. Integration of advanced tools such as genetic engineering, bioinformatics, protoplast fusion, and SNP markers could not be still applied in rice research and development. Hence, emphasis should be given to improve the capacity and abilities of the rice scientists and should release more short duration, drought, and submergence-tolerant rice varieties by optimum utilisation of local landraces combining modern and conventional breeding.

\section{Introduction}

Agriculture is a backbone of Nepal's economy as it contributes $28 \%$ in the national gross domestic product (GDP) as per Nepal Rashtriya Bank [1] and supports livelihood of nearly two-thirds of Nepal's population. Agriculture sector plays a pivot role to increase income, uplift living standard of Nepalese people, and alleviate poverty; however, this sector is not doing well since 1995. Nepalese agriculture is diversified due to the variation in climatic conditions, but it is mainly dominated by three major cereals viz. rice, wheat, and maize. These three cereals jointly account $30.92 \%$ of agricultural GDP of the nation [2] and play vital role in food security and improvement of livelihood. According to FAOSTAT [3], the total cereal production of Nepal in 2018 was 9930178 tonnes and total cereal cultivation area was 
3428987 ha. Rice is one of the most important staple foods for greater than 3.5 billion people in the world [4]. Highest dietary energy is supplied by rice, i.e., 20 percent, while wheat and maize supply 19 and 5 percent, respectively [5]. Hence, rice is the most important crop for food and nutrition security worldwide.

Rice in Nepal is supposed to be introduced from mainland China during the late millennium BC [6]. However, it is believed that commercial production of rice in Nepal started about 500 years ago [7, 8]. The global rice contribution of Nepal is negligible, but it plays a significant role in the national economy. The area, production, and productivity of rice in Nepal was 1491744 ha, 5610011 tonnes, and 3.76 ton/ha in 2019, respectively (Figure 1) [9]. Rice contributes nearly $20 \%$ to the agricultural gross domestic product (AGDP) and almost 7\% to GDP and supplies about $40 \%$ of the food calorie intake to Nepalese people [10].

Nepal used to be a food exporting country till the mid1980s. After that, it has increasingly become a net food importer. During the period of 2009-2013, imports of cereals increased drastically, with trend growth rates of $39 \%$ per annum for rice, $26 \%$ per annum for maize, and $126 \%$ per annum for wheat [11]. Among the world countries, Nepal lies at $72^{\text {th }}$ rank with 22 points in the Global Hunger Index (GHI) [12].

As we know, whole world along with Nepal is severely going to suffer from food insecurity and hunger, so there must be some concrete progressive steps in order to tackle this worldwide problem. It is forecasted that human population will be at peak by the year 2050, and hence, it is estimated that doubling of the crop yield is needed by that period in order to maintain global food security [13]. According to Ray et al. [14], the major crops are unable to achieve the $2.4 \%$ rate of crop production growth per year which is needed to secure the agricultural production by 2050. The case particularly for Nepal is worst as it cannot synch the agricultural production along with rapid population growth rate. It is estimated that population of Nepal reaches about 31.7 million and 35.2 million by mid-2030 and mid-2050, respectively. Hence, to fulfil future hungry mouths, production of agriculture must be enhanced by $70 \%$ [15].

Domestic production is lacking to meet the food demand, and the food import is galloping as the data showed that Nepal imported cereals of NRs. 35.12 billion from India of which rice was imported worth of NRs. 23.79 billion and the maize worth of 7.43 billion in 2013-14 [16]. As the area is limited and cultivable land is shrinking due to increasing human habitats, the best solution we can have is to manipulate and play with the genotypes to increase the genetic yield potential of the genotypes. Hence, plant breeding can play very important part in producing elite and demand driven genotypes by the intelligent use of genetic sources available along with rational utilisation of modern advances and innovations in biotechnology.

This review study deals with the history, recent scenario, and prospects of plant breeding in Nepal, especially focusing on the major cereal crop, rice and rice breeding strategies, in Nepal including public and private organizations. It aims to

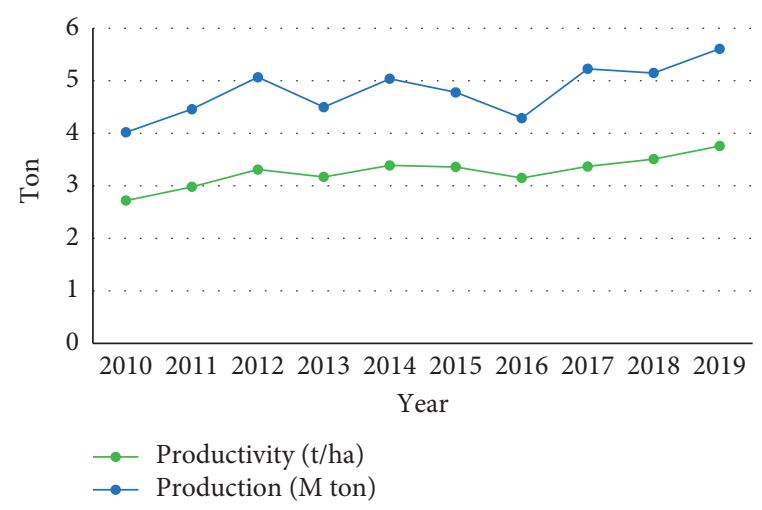

FIgUre 1: Production and productivity of rice in Nepal from 2010 to 2019 [9].

contribute in the agricultural sector to ensure food security and economic growth by highlighting the issues and prospects of rice research and breeding and expected that the information will contribute in advancing plant breeding research in Nepal.

\section{History of Plant Breeding in Nepal}

In Nepal, plant breeding inception point was 1951, which simply started by selection of crops with desired characteristics, while the organised research began in major cereal crops from 1972 after establishing major commodity programs in different agroecological regions. First breeder of Nepal was Netra B. Basnyat and he initiated introducing and collecting different rice varieties and their evaluation. Rice breeding began in Nepal by introducing semidwarf, indicatype varieties from Taiwan [17]. The first recommended variety of rice was $\mathrm{CH}-45$. It was recommended in 1959 by simply evaluating and performing mass selection [7].

For both self- and cross-pollinated crops, mass selection is a very commonly practiced breeding method, while considering only self-pollinated crops and cross-pollinated crops, separately, the pedigree method and recurrent selection are common breeding methods, respectively [17]. According to Joshi [17], Masuli (rice), RR21 (wheat), and Rampur composite (maize) were popular among farmers in 1960 s, and it is considered that due to these varieties, Nepal experienced green revolution. In the early period, i.e., during 1960-1985, breeders were only focused in major cereal crops, but at the ending point of this phase, breeders also started showing some interest on other minor cereals and vegetables [18].

In the midperiod (1985-2005), varieties which were resistant to disease and other biotic stresses got into priority after yield increase. Art was dominant before 1990, but after then, breeding is science-based and less art (Figure 2). According to Ministry of Agricultural Development (MoAD) [19], production of wheat, maize, and rice was surged by $122.3 \%, 90.1 \%$, and $48.9 \%$, respectively, during 1990-2014. Though agricultural imports have increased drastically, domestic production is also increasing slowly. It is thought that plant breeding played a significant role in 


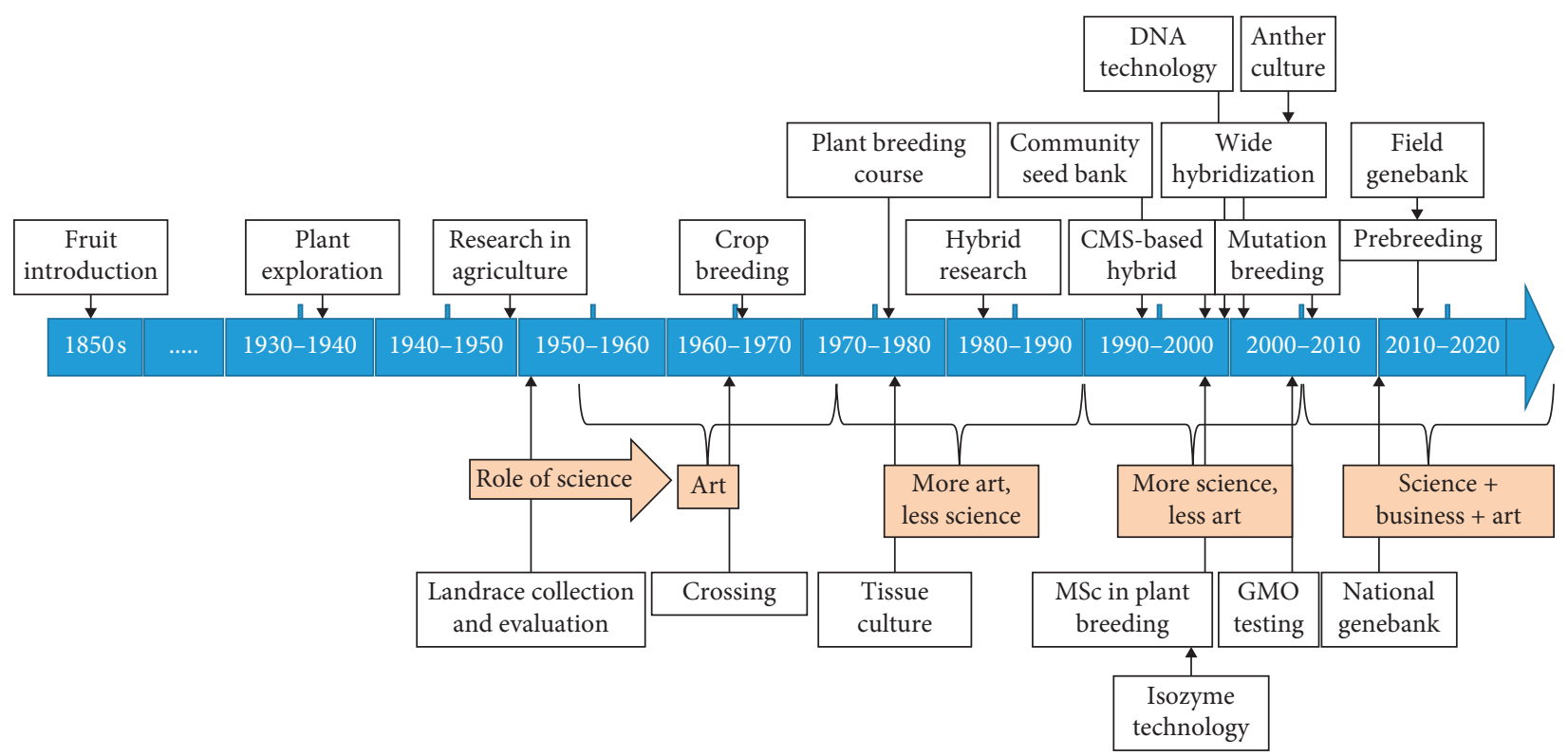

FIgURE 2: Major plant breeding events in Nepal [17].

increasing almost $60 \%$ of total production. Plant breeding research in Nepal got a fast pace after the establishment of NARC in 1991 as an autonomous body under "Nepal Agricultural Research Council Act, 1991," and cereal research got height after a commodity-based research program in 1972 was launched, and different research programs, namely, National Rice Research Program (NRRP), National Wheat Research Program (NWRP), and National Maize Research Program (NMRP) were established to carry organised and focused research on major cereals. Plant breeding does not get significant investment, and only $25 \%$ of total research cost is spent on plant breeding research studies [20].

In Nepal, local germplasm are barely used in research as mostly foreign genetic stocks are preferred. Nepal's dependency on exotic germplasms for research and variety development is $95-100 \%$, and this dependency will further increase due to the impact of climatic change. Local landraces are limitedly used as only 19 crops from local landraces have been utilised in order to develop 41 varieties. Genetic enhancement in landraces was achieved mostly by 2 selection methods, i.e., either through mass or pureline. Nepal has released 275 varieties, among which through introduction accounts the highest, i.e., $71 \%$ followed by $16 \%$ through crossing. Minimum varieties were developed through selection of landraces which is only $13 \%$.

During the journey of nearly 70 years of plant breeding, several testing, methodologies, and procedures have been practiced and utilised in nation. Major plant breeding achievements are introduction of exotic materials and their evaluation, local landraces identification, collection and analysis, crossing of local landraces with exotic genetic materials, heterosis breeding, tissue culture technology, genetic marker technology, and National Genebank. The improved varieties of rice, maize, and wheat cover over $90 \%$ [21], and hence, production and productivity of cereals have been increasing, but the outcome is not as expected. Before 2005 , between wide and site-specific adaptation, wide was preferred by breeders to develop varieties. Among evolutionary and nonevolutionary, nonevolutionary was focused and uniform phenotype was targeted over nonuniform. But in current status, the trend is exactly opposite due to diversity in climate and geography, needs of the farmers, and several other factors. Prebreeding, breeding, and postbreeding are the three activities performed in Nepal to develop varieties.

Among three different breeding methods, namely, conventional, participatory, and modern plant breeding, conventional breeding is dominated and mostly practised in different institutes of Nepal [17]. Introduction, mass selection, heterosis breeding, and maintenance breeding are practiced in Nepal for both self-pollinated and cross-pollinated crops. Mutation breeding, back crossing, pure line selection, bulk method, cultivars mixture, single seed descent, and pedigree method have been practised in selfpollinated crops, while recurrent selection, synthetic variety, and population improvement are only carried out in crosspollinated crops [17]. For vegetatively reproduced crops, different methods such as introduction, selection through clonal, and heterosis breeding are practiced [17]. Shuttle breeding and participatory plant breeding are also practiced in Nepal. Participatory plant breeding is mostly performed in fields of farmers with the involvement of plant breeders. Plant breeders are involved while doing selection and also during advancing segregating generations. Modern plant breeding technologies are not intensively practised in Nepal, as the adoption of these advancements for crop improvement is difficult due to technical problems, financial problems, and lacking of adept manpower. Modern plant breeding uses most of the biotechnological tools, and it can be broadly categorised into three methods, namely, molecular marker technology, tissue culture, and genetic 
engineering. RAPD, SSR and DNA-based markers, are mostly used for diversity appraisal and selecting desirable genotypes. Different tissue culture techniques such as anther culture, meristem tissue culture, somatic hybridization, in vitro fertilization, protoplast fusion, and embryo rescue technique are performed in labs of gene bank and biotechnology. Nepal has not yet started working in genetic engineering [17].

Researchers and plant breeders use different experimental designs. They are randomized complete block design (RCBD), completely randomized design (CRD), alpha lattice design, augmented design, split plot design, unreplicated trial, multilocations trial, and rod row design. Statistical tools commonly used are the AMMI and GGE biplot models for stability analysis, principal component analysis (PCA), and cluster analysis (CA) for multivariate analysis, frequency, mean, coefficient of variation, median, and standard error used in descriptive statistics and for test statistics F-test, $t$-test, LSD, and DMRT. Also, correlation, ANOVA, genetic parameters, and regression are used by researchers. Common softwares used for data analysis are R, GGEBiplot, Minitab, Agrobase, SAS, MSTAT-C, IRRIStat, NTSYS, SPAR, GenStat, Indostat, Alphagen, and Diva-GIS. Similarly, common softwares used by geneticist and biotechnologist are WinQTLCartographer, PHYLIP, MapMaker, PopGene, Genestat, KIN, PowerMarker, GDA, and GenAlex.

\section{Rice Breeding History}

Before 1951, farmers used to practice only selection of local varieties for the rice varietal improvement [7]. Mr. Netra Bahadur Basnyat, the father of rice improvement in Nepal, started introduction and evaluation of high yielding exotic germplasm under his leadership. Initially, exotic Taiwanese rice varieties were introduced in Kathamandu Valley followed by introduction and evaluation of indica rice lines in 1959 at Parwanipur Agricultural Station. After testing various exotic materials, $\mathrm{CH}-45$ was recommended as the first modern variety in 1958 [7]. This variety is still popular among rice cultivars. IR- 8 was released in 1968 as a high yielding variety after introducing and testing of 16 varieties from IRRI and 14 varieties from India [7]. In 1972, at Parwanipur of Bara, a National Rice Research Program (NRRP) was established, and a systematic research in rice was initiated [17]. During this period, semidwarf type varieties Jaya, Durga, Janaki, and Sabitri and intermediate height variety Masuli were identified and released for Terai and inner Terai domain. Masuli became very popular variety among farmers in late 1970-1980s [7]. Before 1980, local varieties were evaluated, but no varieties were released, and mutation breeding was also attempted on local varieties, but no remarkable results were achieved. During early 1970s, hybridization between the local and high yielding exotic germplasm was initiated in Khumaltar and Parwanipur. Identification of resistant germplasm against bacterial blight and blast [22] and for major pests such as plant hopper and stem borer [23] was performed. Before 1980, 17 varieties were released. From 1981 to 2000, 27 varieties were released among which Chaite-6, Radha-7, and Radhakrishna-9 for subtropical Terai and inner Terai areas and Khumal-2 and Khumal-4 for midhills and Palung-2 and Machhapuchhre- 3 were released [24]. Pureline selections on local landrace Chhamroong were performed and released for high altitude cultivation (Table 1). Radha-4, Radha-7, Radha-11, and Radha-12 were released for rainfed lowland areas [24]. Exotic germplasm Rampur Mansuli, a blast resistant variety, was released as a substitute of blast prone Masuli variety in 1999 [26]. Chaite-6, a locally bred variety with high yields and resistance to blast and bacterial blight, was released for the spring season in 1991. Rice scientists classified rice growing environments into irrigated, rainfed lowland, and upland during this period, and varieties were developed accordingly.

Since 2001 to till date, abiotic stresses were more prioritized, and hence, drought-tolerant Sukhadhan-1-6 series varieties having drought tolerant QTL's incorporated through marker-aided selection were released [24]. Likewise, Swarna Sub-1 and Shambha Masuli Sub-1 were released for flashed submerged subtropical areas [24]. Lekhali-1 and Lekhali-3 having a yield of 3.5-4 t/ha were released in Jumla in 2015, which is one of the landmark achievements in the history of rice variety development in Nepal (Table 2). In this period, private sector also got involved in varietal research. An aromatic rice variety Pokhreli Jethobudho for Pokhara area was developed through selection in the collaboration of NARC and LIBIRD (Table 1). Similarly, advanced breeding such as initiation of hybrid rice research [27], molecular diversity, and marker-aided breeding work were also started. Application of biotechnology in rice was started after 2000. Isozymes markers were first used in rice for diversity assessment and finger printing $[28,29]$. Anther culture in rice was initiated since 2002 for double haploid production [30], and embryo rescue was used in interspecific rice hybrids (O. officinalis with indica) [31]. Use of DNA markers technology is increasing for diversity assessment, screening for specific traits, finger printing, conservation as DNA bank, duplicates management, genetic enhancement of landraces, and marker-assisted selection. Screening of 313 Nepalese rice accessions was performed for the presence of submergence tolerance characters using SSR markers [32]. SSR-based screening was also performed in order to identify blast and bacterial leaf blight resistance and drought-tolerant genotypes of rice. By transferring Pi33 gene from IR-64, Jumli Marshi was enchanced for blast resistance with the help of SSR markers. KASP markers are applied for incorporating blast and bacterial leaf blight resistance genes in Khumal-4, Sunaulo Sugandha, Sugandha-1, and Anmol Mansuli. Some of the released rice varieties, e.g., Swarna Sub-1, Sukhadhan-4, and Sambha Masuli Sub-1 were improved through MAS. In case of genetically modified or genetic engineering crops research and development, Nepal is in the embryonic stage, but discussion regarding testing golden rice has been done which is the product of genetic engineering. Molecular marker technology and plant tissue culture are being used by the National Genebank in order to conserve and sustainably utilize Agricultural Plant Genetic Resources (APGR) including rice genetic resources. Nepal 
TABLE 1: List of rice varieties selected from landraces as pure line varieties in Nepal [25].

\begin{tabular}{ccccc}
\hline SN & Varieties/lines & Parents & Grain type & Recommended domain \\
\hline 1 & Chhomrong & Selection of Chhomrong from Ghandruk area of & Coarse & Cool temperate \\
2 & $\begin{array}{c}\text { Pokhareli } \\
\text { Jethobudho }\end{array}$ & Selection of Jethobudho from Pokhara Valley & $\begin{array}{c}\text { Fine and } \\
\text { aromatic }\end{array}$ & $\begin{array}{c}\text { Pokhara Valley and its } \\
\text { surroundings }\end{array}$ \\
3 & Lalka Basmati & Selection of Lalka Basmati from eastern Tarai & $\begin{array}{c}\text { Fine and } \\
\text { aromatic }\end{array}$ & Irrigated eastern and central Tarai \\
\hline
\end{tabular}

TABLe 2: List of rice varieties developed using landraces in Nepal [25].

\begin{tabular}{lcccc}
\hline SN & Varieties/lines & Parents & Grain type & Recommended domain \\
\hline 1 & Khumal-2 & Jameli/Ku-16-361-BLK-2-8 & Fine & Warm temperate \\
2 & Khumal-4 & IR 28/Pokhreli Masino & Fine & Warm temperate \\
3 & Palung-2 & BG 94-2/Pokhreli Masino & Fine & Cool temperate \\
4 & Khumal-5 & Pokhreli Masino/Ku-16-361-BLK-2-6 & Medium & Warm temperate \\
5 & Machhapuchhre-3 & Chhomrong/Fuji 102 & Coarse & Cool temperate \\
6 & Manjushree-2 & Fuji 102/NR10157(Jumli Marshi/IR 9129-159-3//kn-1b-361-1-8-6-3) & Fine & Kathmandu valley \\
7 & Khumal-8 & Jumli Marshi/IR-36 & Fine & Warm temperate \\
8 & Khumal-10 & IR-36/Khumal-5 (Pokhreli Masino/Ku-IB-361-BLR-2-6) & Fine & Warm temperate \\
9 & Lekhali Dhan-1 & Banjaiman/Chhomrong & Coarse & Cool temperate \\
10 & Lekhali Dhan-3 & Yunlen 5/Chhomrong & Coarse & Cool temperate \\
\hline
\end{tabular}

has developed 2 hybrid rice varieties recently in 2020, and private seed traders have been introducing some of the hybrids from neighbouring countries. Out of total cultivated area in Nepal, the share area with hybrid rice varieties was $7.4 \%$ in 2015 [33]. Mutation breeding in rice has been started by NARC, and gamma-ray irradiated seeds of Jumli Marshi, Khumal-4, Sabitri, and Radha-4 were developed. NARC and NAST have sequencing and DNA profiling facilities, but study on and use of genomics in Nepal is not done yet. Hence, information on genomics of Nepalese rice is not available.

Analysing history, mostly foreign materials are used for breeding research. Pedigree analysis reveals that in order to develop Khumal-4 rice variety, 13 landraces originated in 8 different countries were used (Figure 3). Also, a total of 47 landraces from 12 different nations were exploited to develop 20 rice cultivars for mid and high hills. Similarly, 35 landraces originated in 11 different countries were utilised to produce 28 rice cultivars for Tarai. Until 2020, National Seed Board has released and recommended 87 varieties of rice including two hybrids: Hardinath Hybrid-1 and Hardinath Hybrid-10. More than two-thirds of the genetic improvements in rice in Nepal came from IRRI followed by Nepal and India. Remaining rice varieties have been developed by bringing germplasm from China, Taiwan, Philippines, Bangladesh, Sri Lanka, and Indonesia. As of 2019, 50 hybrid varieties of rice have been registered [34].

\section{Different Institutes Involved in Rice Research in Nepal}

The NARC, established in 1991, is the lead organisation for rice varietal improvement to date. NARC has been doing rice research activities such as germplasm conservation, exchange, varietal development, verification of technologies, and knowledge updates in collaboration with various organizations such as IRRI, Local Initiative for Biodiversity, Research and Development (LIBIRD), agricultural universities, Department of Agriculture (DOA), Forum for Rural Welfare and Agricultural Reform for Development (FORWARD), and National Rice Research Program (NRRP). Under NARC, the National Rice Research Program (NRRP) is working on development and evaluation of rice varieties suitable for different agroecological domains (under early, normal, late planting, irrigated, rainfed conditions, lowland and upland areas, spring, boro, and main season planting) of Nepal, development and evaluation of fine and aromatic rice, hybrid rice, submergence, and drought-tolerant rice genotypes and biofortified rice genotypes. Besides this, Agriculture Botany Division (ABD) is conducting leading rice-breeding activities for hills and high hills of Nepal. National Agriculture Genetic Resources Centre (NAGRC) is currently preserving 2300 of rice landraces from various regions of the nation which are made easily accessible to the breeders and students. It has also started prebreeding activities and has screened landraces tolerant to different biotic and abiotic stresses. Similarly, National Research Biotechnology Centre has produced double haploid lines in rice generating F1 from inter and intraspecies crosses, isozyme profiles, RAPD profiles, and SSR profiles of rice. NARC collaborated with Local Initiative for Biodiversity, Research and Development (LIBIRD) on participatory plant breeding (PBB), participatory varietal selection (PVS), client oriented breeding ( $\mathrm{COB})$, wild and wild relatives, rice landraces, germplasm collection, and conservation and utilisation activities in rice. For last couple of decades, NARC and agricultural universities have close collaboration for undertaking agricultural research studies, especially for higher 


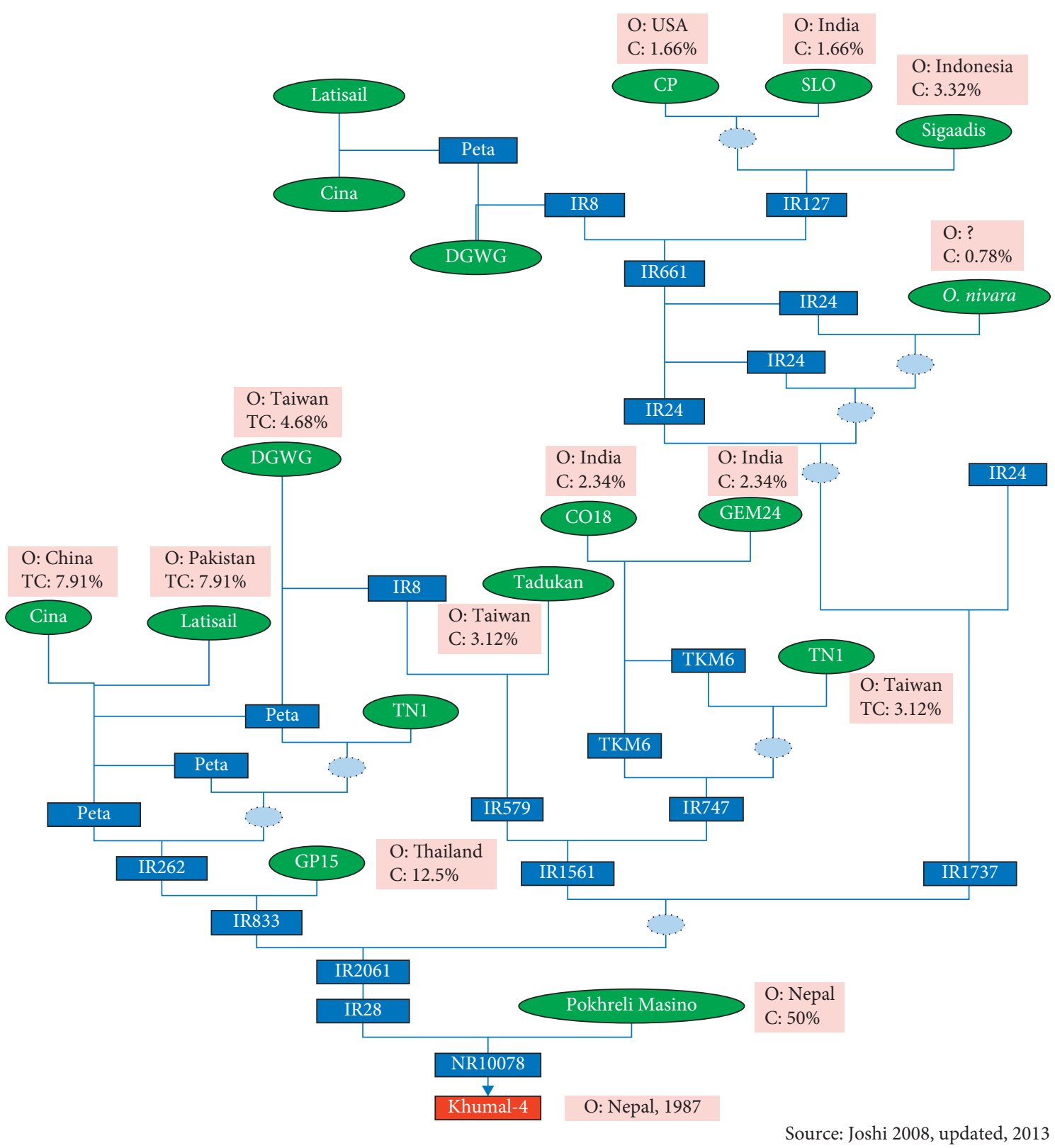

FIgURE 3: Complete pedigree tree of Khumal-4 rice variety [17].

degree research studies by providing research materials and research venues and also scientists from NARC to supervise the students' research work.

\section{Collaboration with IRRI}

IRRI, since 1966, has been providing improved germplasms to Nepal contributing to $70 \%$ of its high yielding inbred rice varieties developed and released for irrigated and rainfed environments. Collaboration between IRRI and Nepal is more than 50 years old, and so far, it has been playing a significant role in hybrid rice development, disease management, improvement in genetics of rice, various abiotic and biotic stress tolerance, various ecosystem based rice lines, and fine and aromatic rice variety development in
Nepal. Among 75 varieties of rice released until 2016, 25 have been developed from germplasm of IRRI. Also, 3000 rice accessions from Nepal have been conserved in IRRI's genebank. Since 2002, hybrid rice research has been initiated in Nepal by the help of IRRI, and Nepal has released two hybrids in 2020, Hardinath Hybrid-1 and Hardinath Hybrid-10, by utilising the crossing parents from IRRI. Nepal recently released 8 drought and 2 submergence tolerant rice varieties with the joint collaboration with IRRI. Nepal has been a member in steering committee like Consortium of Unfavourable Rice Environment (CURE), Consortium of Cold Tolerance Rice Research and Development, Consortium of Hybrid Rice Research and Development, and Development and Consortium of Rice Research in Asia which are coordinated by IRRI. Nepal has been benefitted from the 
TABLe 3: Genotypes with their unique characters found in Nepal [36, 37].

\begin{tabular}{|c|c|c|}
\hline $\mathrm{SN}$ & Genotypes & Unique character \\
\hline 1 & Amaghauj & Multiple spikelet per node \\
\hline 2 & Anadi or Anati & Festival rice/medicinal value/sticky rice \\
\hline 3 & Amaghauj, Budiya dain, Bhati, Jalmardan, Silhat, Lajhi, Karma. & Deepwater rice, water logged, and swampy land \\
\hline 4 & Chhomrong dhan, Darmali, Jumli Marshi & Cold tolerance rice \\
\hline 5 & Ekle & Zinc deficiency tolerance \\
\hline 6 & Gamadhi/Sathi & Enclosed panicle within flag leaf sheath \\
\hline 7 & Ghaiya & Upland rice \\
\hline 8 & Kalanamak Lalka basmati, Kariyakamod & Photoperiod sensitive \\
\hline 9 & Laila Majnu or Jodi dhan & Two grains inside a lemma and palea \\
\hline 10 & Anga, Gurdi, Mansara, Mutmur, Nakhisaro, Thapachiniya & Rainfed upland condition, poor/low fertility \\
\hline 11 & Naltumme & Shade-tolerant rice \\
\hline 12 & Nakhisaro, Sathi, Laltengar & Pest resistant \\
\hline 13 & Patle/P. dhan & Beneficial for pregnant women \\
\hline 14 & R. dhan/Rango & Lodging resistant (strong stem) \\
\hline 15 & Samundaphinj & Water logged and swampy land rice \\
\hline 16 & Sikichan, Tilki, Jirasari & Small grain soft rice \\
\hline 17 & Bageri, Sokan dhan & Resistant to bacterial blight and green leaf hopper \\
\hline 18 & Sotwa, Gajargaul & Medicinal value (fever) \\
\hline 19 & Wild rice & Perenniality gene/festival rice \\
\hline
\end{tabular}

fast-tracked release of a number of improved rice varieties made available from other partner countries by entering the multicountry seed sharing agreement steered by IRRI, referred to as "Seeds without Boarders" in 2014.

\section{Issues and Future Prospects for Rice Research and Breeding in Nepal}

The production of rice is increasing, but the import from India is also galloping. Rice research and breeding is not as satisfactory as much of the germplasm for the released varieties that came from IRRI and other countries, which indicates an inherent weakness in the ability of NARC to develop material independently. Most of the research activities were funded mainly from external sources and often have been tied to IRRI breeding programmes. Similarly, the budget allocations for the rice research are inadequate, and decision-making in research formulations is at best arbitrary and follows traditional orientations. Farmer participation in the breeding programs is not as systematic or effective as it could be. Many technological advances have been made on plant breeding in the world; however, Nepal could not adopt these advances for crop improvement because of lack of financial investments and limited number of breeders. Integration of advanced tools such as genetic engineering, protoplast fusion, bioinformatics, and SNP markers could not be still implemented in research and development of rice. There is a significant gap in public sectors, private sectors, and universities. Farmer preference is not addressed by the breeder due to communication gap. Local landraces are underutilised and not available locally due to the expansion of improved varieties.

Apart from these challenges and hurdles, there lie a lot of opportunities for rice breeders in Nepal. Nepal is known as one of the centres for the diversity of rice as there are 2500 types of landraces including about 50 aromatic landraces. Landraces occupied about $10 \%$ of total rice areas, and there are $9 \%$ of upland type rice landraces [10]. Above 1000 genotypes are introduced annually from IRRI for evaluation [35]. National Agriculture Genetic Resources Centre (NAGRC) is currently preserving 2300 of rice landraces from several regions of the country. There are many landraces with unique characters that have potential yield greater than improved one and are needed to be explored (Table 3). Hence, extensive research using DNA markers are necessary on these landraces, so that the country can become independent on rice genetic materials for further research and development. Establishment of Hybrid Research Unit (HRU) under National Commodity Programs and Divisions are proposed, and by 2025 , it is envisaged that 40 hybrids including 8 rice hybrids will be developed and promoted. In addition, 20 hybrids including 5 rice hybrids are expected to be developed and promoted by private sectors. NARC vision focuses on the use of biotechnological tools in plant breeding with the target of developing high yielding varieties with tolerant/resistant to abiotic and biotic stresses. Also, biotechnology policy has provision on using biotechnology for varietal development. GMOs or their products may be released one after another in the environment by ensuring that no adverse effect to the human health or environment is observed at each stage of the risk assessment [38].

\section{Conclusion}

Huge diversity available in the country should be explored for better designing of genotypes in order to become selfsufficient in rice production. Germplasm accumulation, preservation, characterization, tagging, and mapping of genes along with QTLs in Nepalese rice landraces and their genetic enhancement should be strengthened by using both conventional and molecular techniques. Regional and location specific or niche-based germplasm adaptation should be considered in varietal improvement. Incorporation of molecular breeding such as marker-aided selection along 
with the conventional breeding system for breeding tolerance to biotic and abiotic stresses and for quality traits should be emphasised. Also, integration of advanced tools such as genetic engineering, bioinformatics, protoplast fusion, and SNP markers should be applied in rice research and development. Strong linkage between public and private sectors and research and education is necessary. NARC should focus its breeding program for fine and aromatic rice. Similarly, emphasis should be given to improve the capacity and abilities of the rice scientists and should release more short duration, drought, and submergence tolerant rice varieties.

\section{Data Availability}

The data used to support the findings of this study are available from the corresponding author upon request.

\section{Conflicts of Interest}

The authors declare that they have no conflicts of interest.

\section{References}

[1] NRB, Monetary Policy for 2018/19, National Rastra Bank, Kathmandu, Nepal, 2018, https://www.nrb.org.np/contents/ uploads/2019/12/Monetary_Policy_in_English-2018-19_ Full_Text.pdf.

[2] MoAD, Statistical Information on Nepalese Agriculture 2072/ 2073 (2015/2016), Ministry of Agricultural Development, Kathmandu, Nepal, 2015, https://nepalindata.com/resource/ statistical-information-nepalese-agriculture-207272-201516/.

[3] FAOSTAT, http://www.fao.org/faostat/en/\#data/QC, 2018.

[4] Ricepedia, "The global staple," 2020, http://ricepedia.org/riceas-food/the-global-staple-rice-consumers.

[5] N. Alexandratos and J. Bruinsma, World Agriculture towards 2030/2050: The 2012 Revision, FAO, Agricultural Development Economics Division, Rome, Italy, 2012.

[6] Ricepedia, "History of rice cultivation," 2020, http://ricepedia. org/culture/history-of-rice-cultivation.

[7] R. N. Mallick, "Rice in Nepal," Kala Prakasan, Kathmandu, Nepal, 1982.

[8] H. A. Agrama, W. Yan, M. Jia, R. Fjellstrom, and A. M. McClung, "Genetic structure associated with diversity and geographic distribution in the USDA rice world collection," Natural Science, vol. 2, no. 4, pp. 247-291, 2010.

[9] MOALD, Statistical Information on Nepalese Agriculture 2018/19, Government of Nepal, Ministry of Agriculture and Livestock Development, Planning and Development Cooperation Coordination Division Statistics and Analysis Section, Kathmandu, Nepal, 2018, http://doanepal.gov.np/ downloadfile/Statistical\%20information\%20on\%20Nepalese \%20agriculture_1601976502.pdf.

[10] CDD, Rice Varietal Mapping in Nepal: Implication for Development and Adoption, Crop Development Directorate, Lalitpur, India, 2015, http://www.doacrop.gov.np/ downloadfile/Rice_Varietal_Mapping_1470895701_ 1512106555.pdf.

[11] G. Thapa, A. Kumar, and P. K. Joshi, "Agricultural transformation in Nepal," Prospects, and Policy Options: Trends, Prospects, and Policy Options, Springer, Berlin, Germany, 2019.
[12] K. Grebmer, O. Towey, C. Foley et al., "2017 global hunger index," International Food Policy Research Institute, Washington, DC, USA, 2017.

[13] OECD/FAO, OECD-FAO Agricultural Outlook 2012, OECD Publishing and FAO, Rome, Italy, 2012.

[14] D. K. Ray, N. D. Mueller, P. C. West, and J. A. Foley, "Yield trends are insufficient to double global crop production by 2050," PLoS One, vol. 8, no. 6, Article ID e66428, 2013.

[15] Population Reference Bureau (PRB), 2014 World Population Datasheet, Population Reference Bureau, Washington, DC, USA, 2014, https://www.prb.org/wp-content/uploads/2015/ 11/2014-world-population-data sheet_eng.pdf.

[16] Agro Product Top Import List, The Kathmandu Post, Kathmandu, Nepal, 2015, http://kathmandupost.ekantipur.com/ printedition/news/2015-11-27/agro-products-top-importlist.html.

[17] B. K. Joshi, "Plant breeding in Nepal: past, present and future," Journal of Agriculture and Forestry University, vol. 1, pp. 1-33, 2017.

[18] K. P. Sharma, "Genotypes and management as the determinant factors for soybean production," 9th Summer Crops Workshop, NRIP, Parwanipur, Nepal, 1982.

[19] MoAD, Statistical Information on Nepalese Agriculture 2013/ 2014, Government of Nepal, Ministry of Agricultural Development, Agri-Business Promotion and Statistics Division, Agri statistics Section, Kathmandu, Nepal, 2014.

[20] H. K. Shrestha and S. Gairhe, "Is investment in maize research balanced and justified? An empirical study," Journal of Nepal Agricultural Research Council, vol. 2, pp. 27-32, 2016.

[21] MoAD, Statistical Information on Nepalese Agriculture 2012/ 2013, Government of Nepal, Ministry of Agricultural Development, Agri-Business Promotion and Statistics Division, Agri statistics Section, Kathmandu, Nepal, 2013.

[22] B. P. Upadhyay, "Report on screening for blast resistance in 1977," Proceedings of Fifth Rice Improvement Workshop, National Rice Improvement Program, Parwanipur, Nepal, 1978.

[23] S. Pradhan, "Report on brown plant hopper," Proceedings of Seventh Rice Improvement Workshop, Department of Agriculture, National Rice Improvement Program, Parwanipur, Nepal, 1980.

[24] B. P. Devkota, P. Acharya, and G. Pokhrel, "Released and registered varieties of rice in Nepal and their distribution," in Rice Science and Technology in Nepal, M. N. Paudel, D. R. Bhandari, M. P. Khanal, B. K. Joshi, P. Acharya, and K. H. Ghimire, Eds., pp. 195-205, Crop Development Directorate (CDD), Hariharbhawan and Agronomy Society of Nepal (ASoN), Lalitpur, India, 2017.

[25] H. Upreti, "Distribution patterns of rice landraces in different agro-ecological zones of Nepal," in Rice Science and Technology in Nepal, M. N. Paudel, D. R. Bhandari, M. P. Khanal, B. K. Joshi, P. Acharya, and K. H. Ghimire, Eds., pp. 195-205, Crop Development Directorate (CDD), Hariharbhawan and Agronomy Society of Nepal (ASoN), Lalitpur, India, 2017.

[26] S. P. Khatiwada and H. K. Upreti, "Highlights on rice varieties of various environments of Nepal," in Proceedings of the $3 \mathrm{rd}$ SAS-N Convention, Nepal Agricultural Research Council (NARC), Lalitpur, India, August 2008.

[27] S. P. Khatiwada, S. N. Sah, R. B. Yadav, U. Sah, and B. K. Joshi, "Performance of IRRI bred rice hybrids and future strategy for development of rice hybrids in Nepal," in Proceedings of the 27th National Summer Crops Workshop, vol. 1, pp. 1-8, Tarahara, Nepal, April 2014. 
[28] B. K. Joshi and H. P. Bimb, "Isozymes and molecular based research for crop improvement and management in Biotechnology Unit, NARC," NARC Newsletter, vol. 13, no. 3, 2006.

[29] B. K. Joshi, "Isozymes variation in Nepalese rice (Oryza sativa L.) cultivars," SAARC Journal of Agriculture, vol. 5, no. 1, pp. 95-109, 2007.

[30] B. K. Joshi and H. P. Bimb, "Callus formation ability in anther culture of rice (Oryza sativa L.)," in Proceedings of the 23rd National Summer Crops Research Workshop, H. K. Shrestha, B. Chaudhary, E. M. Bhattrai, and T. Aktar, Eds., NARC, Kathmandu, Nepal, pp. 117-120, December 2003.

[31] R. K. Niroula, L. P. Subedhi, R. C. Sharma, M. P. Upadhyay, M. P. Panday, and N. R. Adhikari, "Embryo culture for interspecific hybridization in the Genus Oryza," in Proceedings of the Abstract, International Conference on Wild Rice, Kathmandu, Nepal, October 2002.

[32] B. G. Tamang, R. K. Niroula, R. B. Amgai, B. P. Sah, and S. K. Ghimire, "Determination of adaptive mechanisms for flash flooding tolerance in Nepalese cultivated rice genepool based on morpho-physiological and molecular analysis," Asian Journal of Plant Sciences, vol. 10, no. 7, pp. 347-356, 2011.

[33] M. N. Paudel and D. R. Bhandari, "Hybrid rice: a paradigm shift from inbred rice," in Rice Science and Technology in Nepal, M. N. Paudel, D. R. Bhandari, M. P. Khanal, B. K. Joshi, P. Acharya, and K. H. Ghimire, Eds., pp. 195-205, Crop Development Directorate (CDD), Hariharbhawan and Agronomy Society of Nepal (ASoN), Lalitpur, India, 2017.

[34] SQCC, Notified and Denotified Varieties of Different Crops, Government of Nepal, Ministry of Agricultural and Livestock Development, Lalitpur, India, 2019, http://sqcc.gov.np/ images/category/Notified_and_Denotified_Varieties_till_ 2076_04_07.pdf.

[35] B. K. Joshi, "Emprical evidence of country interdependence on PGRFA," in Consultation Meeting on Implementation of ITPGRFI-MLSNARC, Lalitpur, India, 2014.

[36] M. P. Upadhyay and B. K. Joshi, Plant Genetic Resources in SAARC Countries: Their Conservation and Management: Nepal Chapter, SAARC Agricultural Information Centre (SAIC), Dhaka, Bangladesh, 2003.

[37] B. K. Joshi, Rice and Wheat Gene Pools in Nepal (1959-2002), National Agriculture Genetic Resources Center, NARC, Lalitpur, India, 2015.

[38] B. Guidelines, National Biosafety Framework Nepal 2006, Ministry of Forests and Soil Conservation, Lalitpur, India, 2005, http://www.fao.org/fileadmin/user_upload/gmfp/docs/ 14\%20National\%20Biosafety\%20Framework\%202006.pdf. 